\title{
Plant Growth Promoting Bacillus spp. and Paenibacillus alvei on the Growth of Sesuvium portulacastrum for Phytoremediation of Salt Affected Soils
}

\author{
P. Kalaiselvi", R. Jayashree and R. Poornima \\ Department of Environmental Sciences, Tamil Nadu Agricultural University, \\ Coimbatore-641003, India \\ *Corresponding author
}

\begin{abstract}
A B S T R A C T
\end{abstract}
\section{Keywords}

Textile effluent, Salt, Remediation, Rhizobacteria, PGPR

Article Info

Accepted:

20 March 2019

Available Online:

10 April 2019
The aim of the study was to isolate and identify the salt tolerant growth promoting bacteria from rhizosphere soil of Sesuvium portulacastrum and also from the soils of dye and textile effluent contaminated sites (Andipalayam, Orathupalayam, Mangalam and Palayakottai villages of Tirupur District, Tamil Nadu) to remediate the salt contaminated soil. On total twenty five strains were selected based on the distinct morphological characters on R2A agar medium supplemented with $3 \% \mathrm{NaCl}$. These strains were further screened for salt tolerance potential and growth with various concentrations of $\mathrm{NaCl}$ $(0.5 \%, 1 \%, 2 \%$ and 3\%). Only 4 strains (OPS2, OPS4, APS1 and APS3) showed the highest salt tolerance potential. The bacterial strain OPS2 has shown the highest removal of salt from the medium. The phylogenetic analysis revealed that 3 strains belonged to Bacillus sp. and a single strain was within Paenibacillus sp. Further these four strains were characterised for plant growth promotion activities. A pot culture experiment was conducted to assess the role of bioamendments and bioinoculants in enhancing salt removal capacity of $S$. portulacastrum. The maximum EC reduction $(72.27 \%)$ and sodium removal $(80.29 \%)$ was observed in the treatment Soil+ Sesuvium portulacastrum applied with Vermicompost $\left(5\right.$ tha $\left.^{-1}\right)$ and Salt tolerant growth promoting rhizobacteria (ST-PGPR).

\section{Introduction}

Textile industries, being a diverse sector, hold almost $14 \%$ of the total industrial production in India. Nearly, 10,000 garment manufacturers and 2100 bleaching and dyeing industries are present in India. An Indian textile industry contributes $80 \%$ of the country's total textiles and operates largely in clusters mainly intensified in states of Tamil Nadu (Tirupur and Karur), Punjab and
Gujarat. With its great demand for water (80$100 \mathrm{~m}^{3} /$ ton of finished textile), safe disposal of the wastewater (115-175 kg of COD/ton of finished textile, a large range of organic chemicals, low biodegradability, colour, salinity) is yet another challenging issue that has to be unravelled due to its complex nature. Main pollution in textile wastewater is from dyeing and finishing processes. With high concentrations of salt these effluents accumulate in various trophic levels of 
ecosystem resulting in a chaos for the agricultural land and water bodies (Bharti and Chauhan, 2013). Totally 6800 ha of agricultural land is affected in Tirupur district due to dye and textile effluents. Around 8.09 million ha is affected with menace of salinity in different climatic regions (Singh et al., 2013). Textile industry wastewater is characterized by high value of BOD, COD, $\mathrm{pH}$ and colour. The $\mathrm{pH}$ range from 5.5 to 10.5 and the EC is 3.5 to $9.1 \mathrm{dSm}^{-1}$. The value of TDS ranges from 1500 to $12000 \mathrm{ppm}$, the TSS and chloride may go up to 8000 and $6000 \mathrm{ppm}$. A wide variation of 400 to 7900 ppm was observed in the sodium concentration of the effluent (Hussein, 2013; Rajeswari et al., 2013; Eswaramoorthi et al., 2008).

Salt accumulation in soils poses problems in two ways: the soil becomes less permeable, and the salt damages or kills the plants. Highly saline soils have high EC, ESP, SAR and are generally poor in availability of macronutrients, micronutrients (Pessarakli and Szabolcs, 1999), organic matter (Qadir et al., 1997), mineralization rates and enzyme activities (McClung and Frankenberger, 1985). Despite which, there are soils with indigenous salt content that includes the clayey soils. The salt content of experimental region usually ranges from 4 to $10.2 \mathrm{dS} \mathrm{m}^{-1}$. Increased salinity limits microbial growth and activity by causing osmotic stress, dehydration and lysis of cells (Wichern et al., 2006). Wong et al., (2008) also observed an increase in metabolic quotient (respiration per unit biomass) with increasing salinity and sodicity, indicating a more stressed microbial community. Intensified salinity also poses direct effect on plants such as a reduction in the osmotic potential of the soil solution that reduces plant available water, a deterioration in the physical structure of the soil such that water permeability and soil aeration are diminished and increase in the concentration of certain ions that have an inhibitory effect on plant metabolism (Grattan and Grieve, 1999).

Amelioration of saline soil involves physical technique (water leaching, deep ploughing, subsoiling, sanding, profile inversion), chemical technique (gypsum, calcium chloride, limestone, sulphuric acid, sulphur, iron sulphate), electro-reclamation (treatment with electric current) and the biological methods including phytoremediation using living or dead organic matter and using microorganisms (Feizi et al., 2010). However, selection and adoption of these technologies depends on soil type, depth of soil to be ameliorated, water available for leaching, quality and depth of groundwater, desired rate of replacement of excessive exchangeable $\mathrm{Na}^{+}$, occurrence of gypsum in soil, availability and cost of amendments, topographic features of the land, nature of the crops to be grown or the land use during and after amelioration, climatic conditions and time available for amelioration.

Salt stress upsets plant-microbe interactions, constituting a critical ecological factor that helps sustain and enhance plant growth in degraded ecosystems. To adapt to saline stressed environments, microorganisms have developed various biochemical strategies over time to maintain structural and functional stability of the cells. As a result, many bacteria are able to synthesize secondary metabolites, such as extracellular enzymes and bioactive compounds. Now there is increasing evidence that the use of beneficial microbes in agricultural production systems can enhance plant resistance to adverse environmental stresses drought, salts, nutrient deficiency and heavy metal contamination. Under adverse environmental stresses, it requires suitable biotechnology to improve not only crop productivity but also soil health through interactions of plant roots and soil 
microorganisms. Development of such a stress tolerant microbial strain associated with roots of agronomic crops can lead to improved fertility of affected soils. Sesuvium portulacastrum is a pioneer plant species used for sand dune fixation, desalination and phytoremediation along coastal regions. The plant tolerates abiotic constraints such as salinity and drought. It is used as vegetables, fodder for domestic animals and as an ornamental plant. It grows at severe salinity of 1000mM NaCl (Lokhande et al., 2013).

Plant growth promoting rhizobacteria (PGPR) - induced plants stress tolerance is considered to be an economic approach to alleviate the salt stress (Barassi et al., 2006). Dodd and Alfocea (2012) reported that isolated PGPR from saline soils improve the plant growth at high salt and it can tolerate wide range of salt stress and enable plants to withstand salinity by hydraulic conductance, osmotic accumulation, sequestering toxic $\mathrm{Na}^{+}$ion maintaining the higher osmotic conductance and photosynthetic activities. The bacteria obtained from saline environment include Flavobacterium, Azospirillum, Alcaligenes, Acinetobacterium, Pseudomonas, Sporosarcina, Planococcus (Ventosa et al., 1983) Bacillus (Upadhyay et al., 2009) Thalassobacillus, Halomonas, Brevibacterium, Oceanobacillus, Terribacillus, Enterobacter, Halobacillus, Staphylococcus and Virgibacillus. Hence, this aims to assess the potential of Sesuvium portulacastrum and their interactions with rhizosphere in remediating salt affected soils (Fig. 1).

\section{Materials and Methods}

Isolation, screening and phylogenetic characterization of bacteria associated with rhizosphere of Sesuvium portulacastrum

Rhizosphere soil of Sesuvium portulacastrum brought from Pitchavaram village in
Chidambaram district of Tamil Nadu was used for isolating salt tolerant bacterial strains using R2A agar medium with $6 \%$ sodium chloride $(\mathrm{NaCl})$. These strains were further screened for salt tolerance and growth in R2A broth amended with various concentrations of $\mathrm{NaCl}(0.5 \%, 1 \%, 2 \%$ and $3 \%)$. The growth was measured at $600 \mathrm{~nm}$ at $72 \mathrm{~h}$.

The potential four salt tolerant bacteria were further selected for phylogenetic identification. Axenically maintained culture was used for DNA isolation. Colonies are picked up with a sterilized toothpick, and suspended in $0.5 \mathrm{ml}$ of sterilized saline in a $1.5 \mathrm{ml}$ centrifuge tube. Centrifuged at 10,000 rpm for $10 \mathrm{~min}$. After removal of supernatant, the pellet is suspended in $0.5 \mathrm{ml}$ of InstaGene Matrix (Bio-Rad, USA). Incubated 56a for 30 min and then heated $100^{\circ} \mathrm{c}$ for $10 \mathrm{~min}$. After heating, supernatant can be used for PCR.

For PCR amplification, $1 \mu \mathrm{l}$ of template DNA was added to the $20 \mu \mathrm{l}$ of PCR reaction solution. The primers 518F/800R was used for amplification, 35 amplification cycles were performed using the following programme $94^{\circ} \mathrm{c}$ for $45 \mathrm{sec}, 55^{\circ} \mathrm{c}$ for $60 \mathrm{sec}$, and $72^{\circ} \mathrm{c}$ for $60 \mathrm{sec}$. The PCR products were purified to remove the unincorporated PCR primers and dNTPs using Montage PCR Clean up kit (Millipore). The purified PCR products of approximately $1,400 \mathrm{bp}$ were sequenced by using the primers (785F 5' GGA TTA GAT ACC CTG GTA 3' and 907R 5' CCG TCA ATT CCT TTR AGT TT 3'). Sequencing were performed by using Big Dye terminator cycle sequencing kit (Applied BioSystems, USA) and the sequenced products were resolved on an Applied Biosystems model 3730XL automated DNA sequencing system (Applied BioSystems, USA).

The culture sequences obtained were subjected to BLAST analysis, the phylogenetically similar type strains sequence 
and other phylogenetic related sequence were selected from the GenBank and they were subjected to multiple sequence alignment and then then align sequences were trimmed to similar length in nucleotides and were subjected to phylogenetic tree (neighbour joining) analysis using MEGA 6. In the tree the numbers at the nodes indicate the levels of the bootstrap support [high bootstrap values (close to $100 \%$ ) meaning uniform support] based on a neighbour-joining analysis of 1,000 re-sampled data sets. The bootstrap values below $50 \%$ were not indicated. Bar 0.005 substitutions per site.

\section{Assay for plant growth promoting abilities Indole 3-acetic acid production}

Indole 3 - acetic acid (IAA) production was analysed calorimetrically (Gordon, 1951) and quantified by growing the bacterium for 7 days in LB- broth supplemented with $100 \mathrm{mg} / \mathrm{L}$ tryptophan as precursor of IAA. For estimation of IAA in the presence of salt, LB - tryptophan was supplemented with different concentrations of $\mathrm{NaCl}$. The grown culture was centrifuged at $10.000 \mathrm{rpm}$. Supernatant was acidified (up to $\mathrm{pH} 2.8$ ) with hydrochloric acid and extracted twice with equal volume of ethyl acetate (Tien et al., 1979). The extracts were further air dried and analysed using high - performance liquid chromatography at a flow rate of $0.5 \mathrm{ml} / \mathrm{min}$ on $\mathrm{C}-18$ column.

\section{Siderophore production}

The CAS solution was prepared by dissolving $60.5 \mathrm{~g}$ of chrome azurol sulphate (CAS) in $50 \mathrm{ml}$ distilled water, and to this, $0.27 \mathrm{~g}$ of $\mathrm{FeCl} 3$ was added and stirred well. To this, $364.6 \mu \mathrm{l}$ of concentration $\mathrm{HCl}$ was added and mixed well. It was slowly added to CATB solution (2.9g CATB in $40 \mathrm{ml}$ distilled water) while stirring, resulting in a dark blue solution $\left(100 \mathrm{ml}\right.$ total) and autoclaved at $121^{\circ} \mathrm{C}$ for 15 minutes. The basal media was prepared by adding $4 \mathrm{~g}$ of succinic acid, $3 \mathrm{~g}$ of $\mathrm{K}_{2} \mathrm{HPO}_{4}$ and $0.2 \mathrm{~g}$ of ammonium sulphate. To this $50 \mathrm{ml}$ of CAS solution was added along the walls of the flask with constant stirring and the $\mathrm{pH}$ was adjusted to 7.0. The volume was then made upto 1L and agar was added and autoclaved. After autoclave, it was cooled and poured in sterile petriplates, each plate receiving approximately $25 \mathrm{ml}$ of blue agar.

After 24 hours (to check any contamination), all the isolates were spot inoculated on these plates and incubated at optimum growth temperature for $3-4$ days. The isolates producing orange colour in the form of halo zone around the colonies were considered as siderophore producers.

\section{Phosphate solubilisation}

The quantitative estimation of solubilized $\mathrm{P}$ by bacterial isolates was done by the vanadomolybdophosphoric yellow colour method (Subba Rao, 1988) in NBRIP (National Botanical Research Institute's Phosphate growth medium) broth (Nautiyal 1999; Mehta and Nautiyal, 2001) containing $1000 \mu \mathrm{g} / \mathrm{ml}$ tri-calcium phosphate (TCP).

\section{Pot culture experiment}

Pot culture experiment was conducted to assess the role of bioamendments and bioinoculants in enhancing salt removal capacity of Sesuvium with the following combinations viz., Soil + Sesuvium portulacastrum, Soil + Sesuvium portulacastrum + Vermicompost $\left(5 \mathrm{tha}^{-1}\right)$, Soil+ Sesuvium portulacastrum + Vermicompost $\left(5\right.$ tha $\left.^{-1}\right)+$ ST-PGPR. The soil collected from Andipalayam village was used in the pot culture experiment. Observation on salt uptake was analysed in soil and plant samples at 0,30 and 60 days after planting in pot culture study 


\section{Field study}

The field experiment to assess the potential of Sesuvium portulacastrum on salt removal was established at Andipalayam Village of Tirupur District. Sesuvium portulacastrum was planted in the field size of $10 \mathrm{ftx} 10 \mathrm{ft}$. The microbial inoculants was mixed with vermicompost and applied to the field and control without inoculum was maintained to compare the salt removal efficiency. The soil physico-chemical characteristics and plant biometric characteristics were monitored at 0 , 30 and 60 days after planting.

\section{Results and Discussion}

Salt tolerant bacteria from rhizosphere soil of Sesuvium portulacastrum taken from Pitchavaram were isolated and twenty five strains were selected based on the distinct morphological characters on R2A agar medium $(3 \% \mathrm{NaCl})$ plates. Colonies were selected based on colour, shape, size and abundance. These strains were further screened for salt tolerance and growth in R2A broth amended with various concentrations of $\mathrm{NaCl}(0.5 \%, 1 \%, 2 \%$ and $3 \%)$. Among these strains, 10 isolates failed to grow during sub culturing and the remaining 15 were screened for further salt tolerance test. The growth was measured at $600 \mathrm{~nm}$ at $72 \mathrm{~h}$. Among the 15 strains only 4 strains (OPS2, OPS4, APS1 and APS3) shown the highest salt tolerance potential (Table 1). The existence of the isolated and screened bacterial strains ( 2 from Orathupalayam soil and 2 from Andipalayam soil) at high salt concentration was tested by further sub culturing in the R2A medium amended with $\mathrm{NaCl}$ and maintained for further characterization and also to study the plant growth promotion activities. The bacterial strain OPS2 has shown the highest removal of salt from the medium followed by OPS4, APS1 and APS3. The highest removal was observed in the $0.5 \%$ concentration. As the concentration increase the removal shown to be less (Table 2).

The morphological and biochemical test of the 4 isolated strains (OPS2, OPS4, APS1 and APS3) is tabulated in Table 3. On the basis of nucleotide sequences of the $16 \mathrm{~S}$ rDNA fragments the selected strains were identified as Paenibacillus alvei (OPS4), Bacillus aryabhattai (APS1), Bacillus vietnamiensis (APS3) and Bacillus megaterium (OPS2). Both Paenibacillus and Bacillus have been reported to provide tolerance to host plants under different abiotic stress environments (Grover et al., 2011). Upadhyay et al., (2011) isolated Paenibacillus from Wheat ( $T$. aestivum) which imparted some degree of tolerance towards salinity stress. Bacillus is one of the most dominant bacteria obtained from saline environment (Upadhyay et al., 2009 and Rodriguez-Valera, 1988). Several halophilic Bacillus species have been isolated from soil samples and it exhibited halophilic properties. Furthermore, Siddikee et al., (2010) reported that Bacillus aryabhattai is able to ameliorate salt stress of $(150 \mathrm{mM})$ in canola plants thereby producing more than 40 per cent increase in root length and dry weight compared to the control.

Moreover, the results of the plant growth promoting potential of the strains indicated that OPS2 (Bacillus megaterium) showed a positive result for all the three tests (IAA production, Siderophore production and Phosphate solubilisation) whereas the other three strains produced IAA only (Table 4). IAA produced by a halo tolerant bacterium will modulate the plant stress level through promoting root growth by stimulating plant cell elongation or cell division (Patten and Glick, 2002, Siddikee et al., 2010). Production of siderophores, an elicitor of induced systemic resistance, is one of the direct stimulation on plant growth and 
development by providing iron that has been sequestered by bacterial siderophores. Solubilisation of phosphorus in rhizosphere increases the nutrient availability to the host plant (Rashid et al., 2004). These rhizobacteria are critical for the transfer of $\mathrm{P}$ from poorly available forms and are important for maintaining $\mathrm{P}$ in readily available pools.

\section{Field study}

The field experiment to assess the potential of Sesuvium portulacastrum on salt removal was established at Andipalayam Village of Tirupur District. Sesuvium portulacastrum was planted in the field size of 10 x $10 \mathrm{ft}$.

The microbial inoculants was mixed with vermicompost and applied to the field and control without inoculum was maintained to compare the salt removal efficiency. The soil physico-chemical characteristics and plant biometric characteristics were monitored at 0 , 30 and 60 days after planting.

Significant growth of plants has been achieved over the experimental period due to the inoculation of microbial consortia. The plants in field study showed higher root (41.4 $\mathrm{cm})$ and shoot length $(42 \mathrm{~cm})$ after 60 days of planting than the pot cultured plants whose root and shoot length are $37.8 \mathrm{~cm}$ and $29.7 \mathrm{~cm}$ respectively (Table 5).

Irrespective of pot and field study the highest biomass content of Sesuvium plant was recorded in the microbial cultures inoculated experiment compared to control at all days of growth.

The maximum biomass of 262 and $475 \mathrm{~g} \mathrm{pot}^{-}$ ${ }^{1}$ wasrecorded in the pot experiment and in the field study respectively at 60 DAP (Table 6). From the table 7, it is evident that the EC and sodium content of the soil tends to decrease over the experimental period. An higher proportional reduction has been attained in field study than in pot culture study, wherein an initial EC of $13.5 \mathrm{dSm}^{-1}$ has reduced to 5.5 (30 DAP) and 3.2 (60 DAP) while the initial concentration of Sodium $\left(3500 \mathrm{mg} \mathrm{kg}^{-1}\right)$ has been reduced to $1750 \mathrm{mg} \mathrm{kg}^{-1}$ (30 DAP) and $700 \mathrm{mg} \mathrm{kg}^{-1}$ (60 DAP).

Assessing the role of bioamendments and bioinoculants in enhancing salt removal capacity of Sesuvium- Pot culture experiment

Pot culture experiment was conducted to assess the role of bioamendments and bioinoculants in enhancing salt removal capacity of Sesuvium with the following combinations viz., Soil + Sesuvium portulacastrum, Soil + Sesuvium portulacastrum + Vermicompost $\left(5\right.$ tha $\left.^{-1}\right)$, Soil+ Sesuvium portulacastrum + Vermicompost $\left(5\right.$ tha $\left.^{-1}\right)+$ ST-PGPR.

The soil collected from Andipalayam village was used in the pot culture experiment. Observation on salt uptake was analysed in soil and plant samples at 0,30 and 60 days after planting in pot culture study.

The initial EC of the Andipalayam village soil ranges between 10.1 to $10.5 \mathrm{dS} \mathrm{m}^{-1}$. Among the treatments, the maximum EC reduction was observed in the treatment Soil+ Sesuvium portulacastrum applied with Vermicompost $\left(5\right.$ tha $\left.^{-1}\right)$ and Salt tolerant growth promoting rhizobacteria (ST-PGPR) recorded the EC of $3.8 \mathrm{dS} \mathrm{m}^{-1}$ (30 DAP) and $2.8 \mathrm{dS} \mathrm{m}^{-1}$ (60DAP).

The initial sodium content Andipalayam village soil ranges from 2980 to $3200 \mathrm{mg} \mathrm{kg}^{-1}$ is reduced to $1420 \mathrm{mgkg}^{-1}$ (30 DAP) and 610 $\mathrm{mgkg}^{-1}$ (60DAP) in the treatment Soil+ Sesuvium portulacastrum applied with Vermicompost $\left(5\right.$ tha $\left.^{-1}\right)$ and ST-PGPR (Table 8). 
Table.1 Bacterial population assessed at $72 \mathrm{~h}_{\text {as }} \mathrm{CFU} \mathrm{ml} l^{-1}$

\begin{tabular}{|c|c|c|c|c|c|}
\hline \multirow{2}{*}{ Strains used } & \multicolumn{5}{|c|}{$\mathrm{NaCl}$ concentration } \\
\cline { 2 - 6 } & Control & $0.5 \%$ & $1 \%$ & $2 \%$ & $3 \%$ \\
\hline OPS2 & $2.0 \times 10-3$ & $6 \times 10-7$ & $4 \times 10-7$ & $7 \times 10-6$ & $8 \times 10-6$ \\
\hline OPS4 & $3.0 \times 10-3$ & $2 \times 10-6$ & $2 \times 10-6$ & $5 \times 10-4$ & $4 \times 10-4$ \\
\hline APS1 & $1.0 \times 10-2$ & $7 \times 10-7$ & $8 \times 10-7$ & $5 \times 10-6$ & $3 \times 10-6$ \\
\hline APS3 & $2.0 \times 10-3$ & $7 \times 10-6$ & $8 \times 10-6$ & $5 \times 10-5$ & $3 \times 10-5$ \\
\hline
\end{tabular}

Table.2 Sodium content in the filtrate in $\mathrm{mg} \mathrm{L}^{-1}$

\begin{tabular}{|c|c|c|c|c|}
\hline \multirow{2}{*}{ Strains used } & \multicolumn{4}{|c|}{$\mathrm{NaCl}$ concentration } \\
\cline { 2 - 5 } & $0.5 \%$ & $1 \%$ & $2 \%$ & $3 \%$ \\
\hline OPS2 & 3570 & 5290 & 10100 & 15300 \\
\hline OPS4 & 2980 & 5090 & 9770 & 13700 \\
\hline APS1 & 2530 & 5350 & 9660 & 14400 \\
\hline APS3 & 3070 & 5380 & 7220 & 10800 \\
\hline
\end{tabular}

Table.3 Morphological, biochemical identification and phylogeny results of the isolated bacterial strains

\begin{tabular}{|c|c|c|c|c|c|}
\hline $\begin{array}{l}\text { Sl. } \\
\text { No. }\end{array}$ & $\begin{array}{l}\text { Morphology and } \\
\text { biochemical test }\end{array}$ & OPS2 & OPS4 & APS1 & APS3 \\
\hline 1. & Morphology & $\begin{array}{c}\text { Small oval } \\
\text { colonies }\end{array}$ & $\begin{array}{l}\text { Round shiny } \\
\text { colonies }\end{array}$ & $\begin{array}{l}\text { Oval rough } \\
\text { colonies }\end{array}$ & $\begin{array}{l}\text { Small oval colonies } \\
\text { with serrated } \\
\text { margins }\end{array}$ \\
\hline 2. & Gram staining & Gram positive & $\begin{array}{l}\text { Gram } \\
\text { negative }\end{array}$ & Gram positive & $\begin{array}{l}\text { Gram } \\
\text { positive }\end{array}$ \\
\hline 3. & Spore shape & - & $\begin{array}{l}\text { Oval and swollen } \\
\text { sporangium }\end{array}$ & $\begin{array}{l}\text { Ellipsoidal } \\
\text { central }\end{array}$ & - \\
\hline 4. & Colony colour & $\begin{array}{l}\text { Dull white to } \\
\text { creamy }\end{array}$ & Yellow & Yellow & $\begin{array}{l}\text { Red to pink } \\
\text { coloured }\end{array}$ \\
\hline 5. & Catalase & + & + & + & + \\
\hline 6. & Oxidase & + & + & + & - \\
\hline 7. & Hydrolysis of casein & + & + & + & + \\
\hline 8. & Hydrolysis of esculin & + & + & - & - \\
\hline 9. & Hydrolysis of Gelatin & + & + & + & - \\
\hline 10. & Nitrate reduction & - & - & - & - \\
\hline 11. & Growth at $3 \% \mathrm{NaCl}$ & + & + & + & + \\
\hline 12. & $\begin{array}{l}\text { Acid production from } \\
\text { glucose }\end{array}$ & + & + & + & + \\
\hline 13. & $\begin{array}{l}\text { Phylogenetic } \\
\text { identification }\end{array}$ & $\begin{array}{l}\text { Bacillus } \\
\text { megaterium }\end{array}$ & $\begin{array}{l}\text { Paenibacillus } \\
\text { alvei }\end{array}$ & $\begin{array}{c}\text { Bacillus } \\
\text { aryabhattai }\end{array}$ & $\begin{array}{c}\text { Bacillus } \\
\text { vietnamiensis }\end{array}$ \\
\hline
\end{tabular}


Table.4 Plant growth promoting traits of salt tolerant bacterial strains used in this study

\begin{tabular}{|c|l|c|c|c|}
\hline $\begin{array}{c}\text { Sl. } \\
\text { No. }\end{array}$ & \multicolumn{1}{|c|}{ Isolate number and location } & $\begin{array}{c}\text { IAA } \\
\text { production }\end{array}$ & $\begin{array}{c}\text { Siderophore } \\
\text { production }\end{array}$ & $\begin{array}{c}\text { Phosphate } \\
\text { solubilization }\end{array}$ \\
\hline 1. & OPS2(Bacillus megaterium) & + & + & + \\
\hline 2. & OPS4(Paenibacillus alvei) & + & - & - \\
\hline 3. & APS1(Bacillus aryabhattai) & + & - & - \\
\hline 4. & APS3(Bacillusvietnamiensis) & + & - & - \\
\hline
\end{tabular}

Table.5 Growth parameters of Sesuvium portulcastrum inoculated with bacterial consortia

\begin{tabular}{|c|c|c|c|c|c|c|c|c|}
\hline \multirow{2}{*}{ Days } & \multicolumn{2}{|c|}{ Pot culture } & \multicolumn{2}{c|}{ Field study } & \multicolumn{2}{c|}{ Pot culture } & \multicolumn{2}{c|}{ Field study } \\
\cline { 2 - 9 } & Control & Inoculated & Control & Inoculated & Control & Inoculated & Control & Inoculated \\
\cline { 2 - 9 } & \multicolumn{2}{|c|}{ Shoot length $(\mathrm{cm})$} & \multicolumn{2}{|c|}{ Shoot length $(\mathrm{cm})$} & \multicolumn{2}{c|}{ Root length $(\mathrm{cm})$} & \multicolumn{2}{c|}{ Root length $(\mathrm{cm})$} \\
\hline 0 & 13.25 & 13.26 & 12.1 & 13.08 & 16.6 & 17.3 & 15.9 & 14.4 \\
\hline 30 & 22.78 & 20.3 & 24.1 & 30.6 & 34.6 & 27.3 & 23.4 & 32.7 \\
\hline 60 & 32.93 & 29.7 & 38.4 & 42.0 & 30.4 & 37.8 & 30.8 & 41.4 \\
\hline Mean & 23 & 21 & 25 & 29 & 27 & 27 & 23 & 30 \\
\hline
\end{tabular}

Table.6 Biomass content $\left(\mathrm{g} \mathrm{pot}^{-1}\right)$ of the Sesuvium portulcastrum inoculated with bacterial consortia

\begin{tabular}{|c|c|c|c|c|}
\hline \multirow{2}{*}{ Days } & \multicolumn{2}{|c|}{ Pot culture } & \multicolumn{2}{c|}{ Field study } \\
\cline { 2 - 5 } & Control & Inoculated & Control & Inoculated \\
\hline 30 & 56 & 172 & 90 & 255 \\
\hline 60 & 173 & 262 & 270 & 475 \\
\hline Mean & 115 & 217 & 180 & 365 \\
\hline
\end{tabular}

Table.7 EC and Sodium content of the Sesuvium portulcastrum cultivated soil inoculated with bacterial consortia

\begin{tabular}{|c|c|c|c|c|c|c|c|c|}
\hline \multirow[t]{3}{*}{ Days } & \multicolumn{2}{|c|}{ Pot culture } & \multicolumn{2}{|c|}{ Field } & \multicolumn{2}{|c|}{ Pot culture } & \multicolumn{2}{|c|}{ Field } \\
\hline & Control & Inoculated & Control & Inoculated & Control & Inoculated & Control & Inoculated \\
\hline & \multicolumn{4}{|c|}{$\mathrm{EC}\left(\mathrm{dSm}^{-1}\right)$} & \multicolumn{4}{|c|}{$\mathrm{Na}\left(\mathrm{mgkg}^{-1}\right)$} \\
\hline 0 & 13.5 & 13.5 & 13.5 & 13.5 & 3500 & 3500 & 3500 & 3500 \\
\hline 30 & 6.5 & 7.5 & 8.5 & 5.5 & 1950 & 1900 & 1850 & 1750 \\
\hline 60 & 4.0 & 4.5 & 5.5 & 3.2 & 980 & 850 & 870 & 700 \\
\hline Mean & 8 & 9 & 9 & 7 & 2143 & 2083 & 2073 & 1983 \\
\hline
\end{tabular}


Table.8 EC and Sodium content of the Sesuvium portulcastrum cultivated soil

\begin{tabular}{|c|c|c|c|c|c|c|}
\hline Treatments & \multicolumn{3}{|c|}{$\mathrm{EC}\left(\mathrm{dSm}^{-1}\right)$} & \multicolumn{3}{c|}{$\mathrm{Na}\left(\mathrm{mgkg}^{-1}\right)$} \\
\cline { 2 - 7 } & Initial & 30 DAP & 60 DAP & Initial & 30 DAP & 60 DAP \\
\hline $\begin{array}{c}\text { Soil + Sesuvium } \\
\text { portulacastrum }\end{array}$ & 10.3 & 6.2 & 4.5 & 3200 & 1800 & 880 \\
\hline $\begin{array}{c}\text { Soil + Sesuvium } \\
\text { portulacastrum + } \\
\text { Vermicompost (5tha-1) }\end{array}$ & 10.5 & 4.8 & 3.1 & 2980 & 1580 & 730 \\
\hline $\begin{array}{c}\text { Soil+ Sesuvium } \\
\text { portulacastrum + } \\
\text { Vermicompost (5tha-1)+ } \\
\text { ST-PGPR }\end{array}$ & 10.1 & 3.8 & 2.8 & 3095 & 1420 & 610 \\
\hline
\end{tabular}

Table.9 Growth and biomass content of Sesuvium portulcastrum

\begin{tabular}{|c|c|c|c|c|c|c|c|c|c|}
\hline \multirow{2}{*}{ Treatments } & \multicolumn{3}{|c|}{ Root length $(\mathrm{cm})$} & \multicolumn{3}{c|}{ Shoot length $(\mathrm{cm})$} & \multicolumn{4}{c|}{ Biomass (g pot-1) } \\
\cline { 2 - 11 } & Initial & $\begin{array}{c}30 \\
\text { DAP }\end{array}$ & $\begin{array}{c}60 \\
\text { DAP }\end{array}$ & Initial & $\begin{array}{c}30 \\
\text { DAP }\end{array}$ & $\begin{array}{c}60 \\
\text { DAP }\end{array}$ & Initial & 30 DAP & 60 DAP \\
\hline $\begin{array}{c}\text { Soil + Sesuvium } \\
\text { portulacastrum }\end{array}$ & - & 12.3 & 18.5 & 5.8 & 16.2 & 21.5 & 25 & 163 & 175 \\
\hline $\begin{array}{c}\text { Soil + Sesuvium } \\
\text { portulacastrum + } \\
\text { Vermicompost (5tha-1) }\end{array}$ & - & 18.7 & 23.6 & 5.3 & 21.7 & 28.2 & 30 & 280 & 430 \\
\hline $\begin{array}{c}\text { Soil+ Sesuvium } \\
\text { portulacastrum + } \\
\text { Vermicompost (5tha-1)+ } \\
\text { ST-PGPR }\end{array}$ & - & 20.2 & 25.7 & 6.1 & 20.4 & 30.5 & 26 & 320 & 570 \\
\hline
\end{tabular}

Table.10 EC and Sodium content of the Sesuvium portulcastrum

\begin{tabular}{|c|c|c|c|c|c|c|}
\hline Treatments & \multicolumn{3}{|c|}{ EC (dSm-1) } & \multicolumn{3}{c|}{$\mathrm{Na}(\%)$} \\
\cline { 2 - 7 } & Initial & 30 DAP & 60 DAP & Initial & 30 DAP & 60 DAP \\
\hline $\begin{array}{c}\text { Soil + Sesuvium } \\
\text { portulacastrum }\end{array}$ & 8.5 & 11.2 & 14.7 & 3.5 & 3.9 & 4.1 \\
\hline $\begin{array}{c}\text { Soil + Sesuvium } \\
\text { portulacastrum + } \\
\text { Vermicompost (5tha-1) }\end{array}$ & 8.7 & 10.3 & 11.9 & 3.1 & 3.4 & 3.7 \\
\hline $\begin{array}{c}\text { Soil+ Sesuvium } \\
\text { portulacastrum + } \\
\text { Vermicompost (5tha-1)+ } \\
\text { ST-PGPR }\end{array}$ & 8.4 & 9.7 & 10.6 & 3.0 & 3.2 & 3.5 \\
\hline
\end{tabular}


Fig.1 Phylogenetic position of the isolates recovered from rhizosphere soil of Sesuvium portulacastrum. The phylogeny analysis was carried out using Mega 4.0, the distance was calculated using Kimura two parameter model and clustering with using Neighbour joining algorithm. Bootstrap values were determined based on 1000 replications. Bar indicates 0.01 substitutions per site

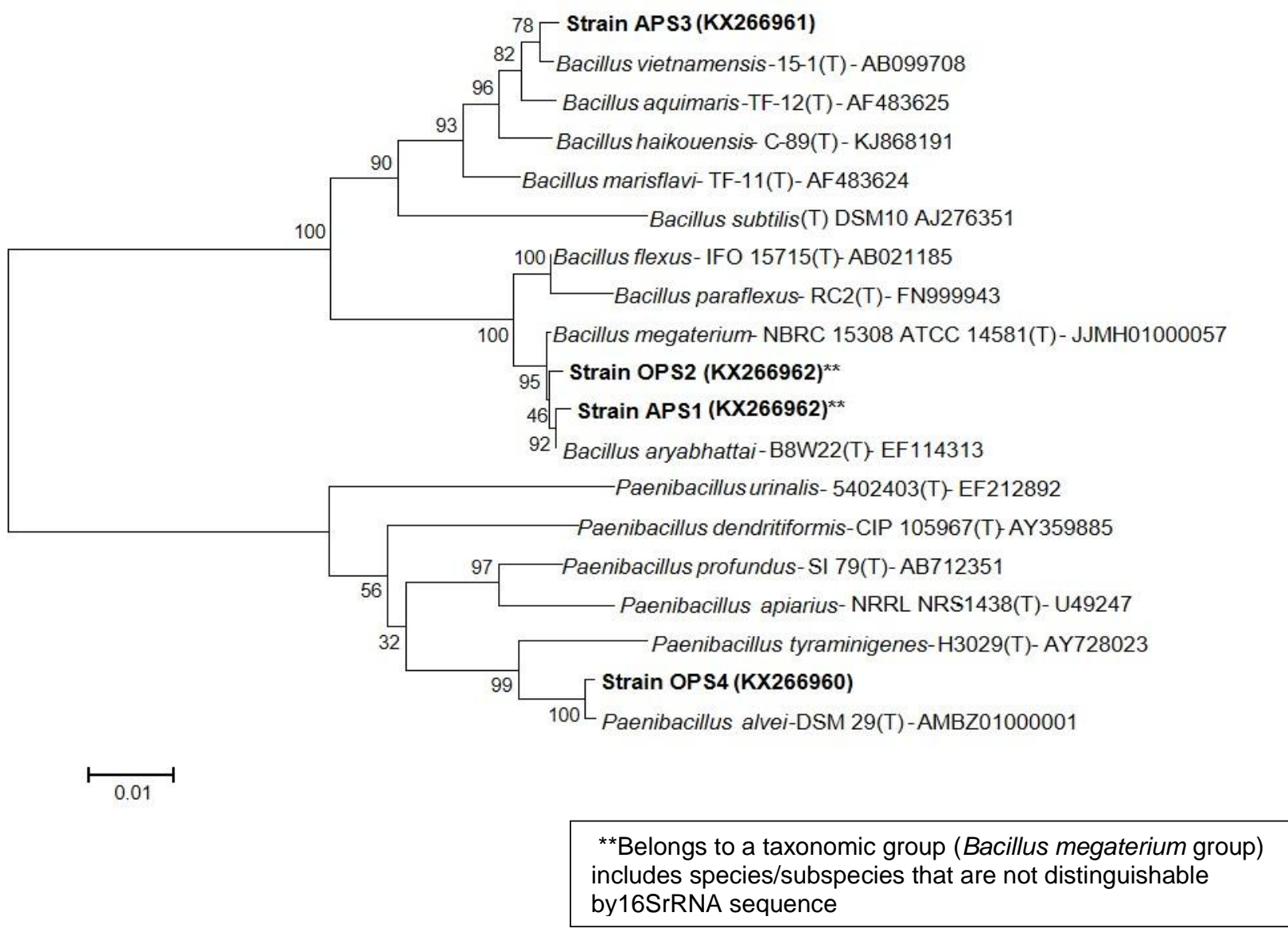

The maximum root length $(25.7 \mathrm{~cm})$, shoot length $(30.5 \mathrm{~cm})$ and biomass $\left(570 \mathrm{~g} \mathrm{pot}^{-1}\right)$ was observed in the treatment Soil+Sesuvium portulacastrum applied with Vermicompost (5tha ${ }^{-1}$ ) and ST-PGPR (Table 9).

The initial sodium content Sesuvium portulcastrum is from 3.0 to $3.5 \%$. The lowest sodium content of $3.5 \%$ was observed in the plant in the treatment Soil+ Sesuvium portulacastrum applied with Vermicompost $\left(5\right.$ tha $\left.^{-1}\right)$ and ST-PGPR at 60DAP.The highest sodium content was observed in the plant in the treatment Soil+ Sesuvium portulacastrumwas4.1\% at60DAP (Table 10).
The results in the pot culture experiment were mirrored on the field study also, as the plants able to withstand the salt stress and adopt to the soil conditions. It was already documented that is can able to withstand a salt spray and grows in the coastlines in the tropical and sub-tropical shore line (Lokhande et al., 2012). Generally, under salt stress condition, in $S$. portulacastrum decrease in the root and shoots leading to lesser biomass accumulation. However, in the present study due to the presence of the plant growth promoting Bacillus sp. the roots, shoot and biomass level were increased in the inoculated plants. Similar effects on plant 
growth promoting bacteria were documented earlier by halotolerant bacteria like Brevibacterium, Planococcus, Zhihengliuella, Halomonas, Exiguobacterium, Oceanimonas, Corynebacterium, Arthrobacter, and Micrococcus (Siddikee et al., 2010). Thus the present also emphasise the need for a phytoremediating agent ( $S$. portulacastrum) and bioinoculants to augment the salt stress under salt contaminated soils.

In conclusion, the experimental results revealed that these bacterial strains having salt tolerant potential and also PGPR activities so this can be effectively utilized as a bioinoculant for better crop growth in the salt affected soils.

\section{References}

Barassi, C., Ayrault G., Creus C., Sueldo, R and Sobrero M. (2006). Seed inoculation with Azospirillum mitigates $\mathrm{NaCl}$ effects on lettuce. Scientia Horticulturae, 109: 8-14.

Bharti, P.K., and Chauhan, A., (2013). Soil quality and contamination, Discovery Publishing House, New Delhi, India p. 186

Dodd, I.C., and Perez-Alfocea, F., (2012). Microbial amelioration of crop salinity stress. J. Exp. Bot. 63: 3415-3428

Eswaramoorthi, S., Dhanapal K., and Chauhan, D. (2008). Advanced in textile wastewater treatment: The case for UV-ozonation and membrane bioreactor for common effluent treatment plants in Tirupur, Tamil Nadu, India. Coimbatore, India: Environment with People's Involvement \& Co-ordination in India.

Feizi, M., Hajabbasi, M.A. and Mostafazadeh, F.B. (2010). Saline irrigation water management strategies for better yield of safflower (Carthamus tinctorius L.) in an arid region. Aust. J. Crop Sci., 4:
408- 414.

Grattan, S.R., Grieve C.M. (1999). Mineral nutrient acquisition and response by plants grown in saline environments. In: Pessarakli M. (Ed.): Handbook of Plant and Crop Stress. Marcel Dekker, New York: 203-229.

Grover, M., Ali, Sk. Z., Sandhya, V., Rasul, A., Venkateswarlu, B. (2011).Role of microorganisms in adaptation of agriculture crops to abiotic stresses. World J. Microbiol. Biotechnol., 27: 1231-1240.

Gordon, S.A., and Weber R.P. (1951).Colorimetric estimation of indole-acetic acid. Plant Physiol., 26: 192-195.

Hussein, F.H., (2013). Chemical properties of treated textile dyeing wastewater. Asian J Chem 25:9393-9400.

Lokhande, V.H., Gor B.K., Desai N.S., Nikam T.D. and Suprasanna P. (2013). Sesuvium portulacastrum, a plant for drought, salt stress, sand fixation, food and phytoremediation. A review Agron. Sustain. Dev 33: 329-348.

Manzoor, Q., Rizwan Q., and Nawal A., (1997). Nutrient availability in a calcareous saline-sodic soil during vegetative bioremediation. Arid Land Res. Manag. 11: 343-352.

Mcclung, G., and Frankenberger, W., (1985). Soil nitrogen transformations as affected by salinity. Soil Science. 139: 405-411.

Mehta, S., and Nautiyal, C., (2001). An efficient method for qualitative screening of phosphate-solubilizing bacteria. Curr Microbiol 43: 51-56.

Nautiyal, C.S., (1999). An efficient microbiological growth medium for screening phosphate solubilizing microorganisms. FEMS Microbiol Lett. 170:265-70.

Patten, C.L., and Glick, B.R. (2002). Role of Pseudomonas putida indoleacetic acid 
in development of the host plant root system. Appl. Envtl. Microbiol., 68: 3795-801.

Pessarakli, M., and Szabolcs I., (1999). Soil salinity and sodicity as particular plant/crop stress factor. In $M$. Pessarakli (ed.), Handbook of Plant and Crop Stress. Marcel Dekker Press Inc. New York, pp. 1-16.

Rajeswari, K., Subashkumar R., and Vijayaraman K. (2013). Physicochemical parameters of effluents collected from Tirupur textile dyeing and CETP and analysis of heterotropic bacterial population. $\mathrm{J}$ Microbiol Biotechnol Res 3:37-41.

Rashid, M., Khalil, S., Ayub, N., Alam, S and Latif, F. (2004). Organic acids production and phosphate solubilization by phosphate solubilizing microorganisms (PSM) under in vitro conditions. Pak. J. Biol. Sci., 7, 187-196.

Rodriguez-Valera, F., (1988). Characteristics and microbial ecology of hypersaline environments, pp. 71-84. In: Halophilic bacteria. Vol 1 (F. Rodriguez-Valera, (Ed.). Boca RatonJFL CRC Press Inc.

Siddikee, M., Puneet, C., Rangasamy, A., Gwang-Hyun H and Sa. T.M. (2010). Isolation, characterization, and use for plant growth promotion under salt stress, of ACC deaminase-producing halotolerant bacteria derived from coastal soil. J. Microbiol Biotechnol. 20: 1577-1584.

Singh, Y.P., Dubey U.C, Singh S and Dubey
S.K. (2013). Interventions of sodic soil reclamation technologies and constraints in their adoption. Indian Res. J. Ext. Edu. 13:36-40.

Subbarao, N.S., (1988). Phosphate solubilizing microorganism. In: Biofertilizer in Agriculture and forestry. Regional Biofert. Dev. Centre, Hissar, India, 133-142.

Tien, T., Gaskin, M., and Hubbel, D. .(1979). Plant growth substances produced by Azospirillum brasilense and their effect on the growth of pearl millet (Pennisetum americanum L.). Appl Environ. Microbiol. 37: 1016-1024.

Upadhyay, S.K., Singh D.P and Saikia, R. (2009). Genetic diversity of plant growth promoting rhizobacteria isolated from rhizospheric soil of Wheat under saline condition. Curr. Microbiol., 59:489-496.

Upadhyay, S.K., Singh, J.S., Saxena, A.K and Singh D.P. (2011).Impact of PGPR inoculation on growth and antioxidant status of wheat under saline conditions. Plant Biol., 14: 605-611.

Ventosa, A., Ramos-Cormenzana, A and Kocur, M. (1983). Moderately halophilic Gram-positive cocci from hypersaline environments. Sys. Appl. Microbiol. 4: 564-570.

Wichern J., Wichern F., and Joergensen R.G., (2006). Impact of salinity on soil microbial communities and the decomposition of maize in acidic soils. Geoderma 137: 100-108.

\section{How to cite this article:}

Kalaiselvi, P., R. Jayashree and Poornima, R. 2019. Plant Growth Promoting Bacillus spp. and Paenibacillus alvei on the Growth of Sesuvium portulacastrum for Phytoremediation of Salt Affected Soils. Int.J.Curr.Microbiol.App.Sci. 8(04): 2847-2858. doi: https://doi.org/10.20546/ijcmas.2019.804.332 